\title{
KNIGHTHOOD IN THE GRAND DUCHY OF LITHUANIA FROM THE LATE FOURTEENTH TO THE EARLY SIXTEENTH CENTURIES*
}

\author{
Rimvydas Petrauskas
}

ABSTRACT The main aim of this article is to collect and assess all accessible data about the early development of chivalric culture in the GDL and to identify possible trends. This phenomenon is perceived as part of the history of the European knighthood in the late Middle Ages. The article also seeks to investigate the meaning of the conception of the knight in the GDL documents of the fifteenth century in order to determine the spread of knighthood in the nobility of the Grand Duchy. In the research of these aspects the flourishing of the knighthood culture at the court of Grand Duke Vytautas in the early-fifteenth century is distinguished as a period when high-ranking representatives of the country's nobility were awarded titles; and a new enhancement is noticeable in the times of Alexander Jogailaitis when an initiative, a unique phenomenon in Poland-Lithuania, was undertaken to establish a brotherhood of knights. In the analysis of the use of the concept of knighthood, emphasis is placed on the difference between the singular use of the knightly title and the pluralistic estate conception.

In 1446 the grand master of the Teutonic Order sent a letter of credence to Grand Duke Casimir and the palatine of Vilnius, Jonas Goštautas, to the effect that that the noble knights Hans Marschalk and Jenichen von Tergowitz were going to visit the courts of the Lithuanian ruler, and other nobles and dukes in order to gain knowledge of knighthood there: Die edelen und vesten Hans Marschalk und Jenichen von Tergouitz...haben liebe und lust und sint geneiget euwer grosmechtikeit und andern hern und fursten hoeffe, landt und gegenaten zcu besuchen, sich darinne zcu sehen und

* This article is part of the project 'Political, Ethnic, and Religious Confrontations in Lithuania in the Thirteenth - Fifteenth Centuries' financed by the Lithuanian State Foundation for Research and Studies 2006. 
ritterschaft zcu uben. ${ }^{1}$ The letter was a customary sort of correspondence among rulers in the late Middle Ages - it was connected with the growing custom of journeys made by the noblemen (Kavalierstour) for promoting knighthood. ${ }^{2}$ The aims of such trips were varied - from diplomatic activity to the search for exotic countries and customs. However, pursuit of fostering knighthood was a primary motive. Therefore, it is understandable that the origins of these journeys go back to the times of the crusades against the pagans and Muslims. ${ }^{3}$ In the fourteenth century pagan Lithuania was an area of such campaigns where the knights of Europe from Portugal to Hungary had an excellent chance to perform knightly rituals and strengthen their corporate position. ${ }^{4}$ It is difficult to determine to what extent this knightly culture, developing in Prussia, affected the life of Lithuania's nobility. Nevertheless, there is every indication that communication between the noblemen of the warring parties was not at all confined to military activities. ${ }^{5}$ Sources even contain descriptions of the battles between pagan dukes and Christian noblemen that

${ }^{1}$ Ms: Berlin, Geheimes Staatsarchiv Preußischer Kulturbesitz [henceforth GStA PK], Ordens Foliant 16, pp. 1152-1154. The documents are published by S. C. Rowell, 'Du Europos pakraščiai: Lietuvos Didžiosios Kunigaikštystės ir ispanu karalysčių ryšiai 1411-1412 ir 1434 m. tekstuose“, Lietuvos istorijos metraštis 2003/ 1 (Vilnius, 2004), pp. 187-188. See also R. Petrauskas, Lietuvos diduomené XIV a. pabaigoje $-X V$ a.: sudètis - struktūra - valdžia (Vilnius, 2003), p. 152. Jenichen was born into a family, active in the work of the Lizard Society, uniting Prussian knights (J. Voigt, Geschichte der Eidechsen-Gesellschaft in Preußen (Königsberg, 1823), p. 67).

${ }^{2}$ See W. Paravicini, 'Fürschriften und Testimonia. Der Dokumentationskreislauf der spätmittelalterlichen Adelsreise am Beispiel des kastilischen Ritters Alfonso Mudarra 1411-1412‘, Studien zum 15. Jahrhundert. Festschrift für Erich Meuthen, eds J. Helmrath und H. Müller, vol. 2 (Munich, 1994), pp. 903-936. On the phenomenon of noblemen's journeys in the European context, see Grand Tour. Adeliges Reisen und europäische Kultur vom 14. bis zum 18. Jahrhundert, eds R. Babel und W. Paravicini (Ostfildern, 2005).

3 W. Paravicini, 'Von der Heidenfahrt zur Kavalierstour. Über Motive und Formen adligen Reisens im späten Mittelalter', Wissensliteratur im Mittelalter und in der Frühen Neuzeit, eds H. Brunner und N. Richard Wolf, (Wissensliteratur im Mittelalter, vol. 13) (Wiesbaden, 1993), pp. 91-130.

${ }^{4}$ E. Maschke, 'Burgund und der preussische Ordensstaat. Ein Beitrag zur Einheit der ritterlichen Kultur Europas im späten Mittelalter', E. Maschke, Domus hospitalis Theutonicorum. Gesammelte Aufsätze (Bonn-Bad Godesberg, 1970), pp. 1534; and in particular W. Paravicini, Die Preußenreisen des europäischen Adels, vols. 12 (Sigmaringen, 1989-1994).

${ }^{5}$ In greater detail, see R. Petrauskas, 'Tolima bičiulystè: asmeniniai Vokiečių ordino pareigūnų ir Lietuvos valdovų santykiai' (in preparation). 
were regulated by chivalric customs. ${ }^{6}$ The Lithuanian ruling elite took over some customs of European knights, such as certain elements of warfare and tactics, behaviour with prisoners, etc. ${ }^{7}$ The appearance of new power symbols also reflects the changes in the selfconsciousness of the Lithuanian nobility. Władysław Semkowicz states expressly that the new coats of arms of the Lithuanian nobility that appeared at the turn of the fourteenth and fifteenth centuries (before the Union of Horodło) replicated the style of Western coats of arms. ${ }^{8}$ After accepting Christianity in the late fourteenth century and being no more an object of crusades, in the fifteenth century Lithuania became a country where one could go 'to learn knighthood'. There is no evidence about the further fate of the two knights of the Order in Lithuania and about their expectations or the results of their trip. However, the motive itself (even though expressed in a traditional clerical phrase) for visiting the court of the grand duke displays the image of Lithuanian knighthood in the perception of the nobility of the neighbouring states.

In 1431 at the height of the conflict with the Poles, a group of Lithuanian noblemen sent a letter to the grand master of the Order to the effect that the Polish behaviour contradicted 'Christian and knightly customs'. ${ }^{9}$ This incident from the life of the noblemen of the GDL shortly after Vytautas' death prompts the researcher to take a closer look at the phenomenon of knighthood in Lithuania and to try to determine what social and cultural content is hidden behind this knightly rhetoric.

In Lithuanian historical scholarship various aspects of knighthood have been investigated by Matvei Liubavskii, Edvardas Gudavičius, Stanislovas Lazutka, Alvydas Nikžentaitis, Kastytis Antanaitis and Jūratė Kiaupienè. ${ }^{10}$ The merit of Gudavičius and Lazutka is the differentiation

${ }^{6}$ See A. Nikžentaitis, 'XIII-XIV a. lietuvių kariuomenès bruožai (organizacija, taktika, papročiai)', Karo archyvas, 13, 1992, pp. 3-33 (in particular pp. 29-31).

${ }^{7}$ A. Nikžentaitis, 'Belaisviai Lietuvoje ir Vokiečiu ordino valstybejje (12831409)', Lietuvos valstybe XII-XVIII a. (Vilnius, 1997), pp. 507-527.

${ }^{8} \mathrm{~W}$. Semkowicz, 'Braterstwo szlachty polskiej z bojarstwem litewskiem w unji horodelskiej 1413 roku', Polska i Litwa w dziejowym stosunku (Cracow, 1914), p. 414 ff.; repr. in Lituano-Slavica Posnaniensia: Studia historica, 3 (1989), pp. 7-139.

${ }^{9}$ GStA PK, OF 14, pp. 599-600: 'wedir gewonheyt cristlicher und ritterlicher lowte".

${ }^{10}$ M. K. Liubavskii, Litovsko-russkii seim (Moscow, 1900), p. 454 ff.; E. Gudavičius, 'Šlèktų atsiskyrimas nuo bajorų Lietuvoje XVI a. (1. Bajorų luomo susidarymas XV a.)', Lietuvos TSR Mokslu Akademijos darbai. Serija A, 2, 1975, pp. 97-106; 
of two senses of the concept 'knighthood': a) representative (as part of chivalric culture) and b) attributive (as the general characteristic of the gentry as an estate). Nikžentaitis was concerned with the earliest forms of knighthood in Lithuania, and Kiaupiene showed the transition of the image of the GDL knight between the late medieval and early modern periods against a broad historiographical background.

Nevertheless, there remain a number of issues awaiting investigation. In the first place, these are related to the spread of chivalry and its place in the world outlook of the GDL nobility and gentry. Consequently, one of the main aims of this paper is to gather and assess all available data about the early knightly culture in the GDL and to determine its possible tendencies. Its spread in Lithuania is perceived as part of the late-medieval history of European chivalry, therefore this study is preceded by a brief overview of the history of European knighthood. The other aim of this article is the analysis of the significance of the concept of the knight in fifteenth-century documents from the GDL, possibly leading to a better understanding of the spread of knighthood among the nobility of the GDL. This is important merely because in historical scholarship knights are often confused with the horsemen doing their military service, disregarding the specifics of the concept 'the knight'.11

\section{Knighthood in the Late Medieval Period Like many} fundamental concepts 'the knight' and 'knighthood' underwent significant changes over time. In the late Roman Empire the words militia and miles denoted terms relating to the service in the army and administration. The sign of this service - a belt (cingulum militiae) - indicated the connection between the classical and medieval perception of knighthood. In the Middle Ages 'knight' meant a mounted warrior

E. Gudavičius, S. Lazutka, 'Riteriai', Lietuvos istorijos metraštis 1980 (Vilnius, 1981), pp. 105-109; A. Nikžentaitis, 'XIII-XIV a. lietuvių kariuomenès bruožai' (see note 6); K. Antanaitis, 'Riterijos apraiškos Lietuvoje XIV-XVI amžiais', Darbai ir Dienos, 5(14) (1997), pp. 125-142; J. Kiaupienè, 'Lietuvos Didžiosios Kunigaikštystès riterio vaizdinys Motiejaus Stryjkovskio tekstuose', Kultūru sankirtos. Skiriama doc. dr. Ingès Lukšaitès 60-mečiui, ed. Z. Kiaupa et al. (Vilnius, 2000), pp. 117-141 (this paper contains a review of earlier works, too).

${ }^{11}$ Therefore Antanaitis' assumption about several hundred knights in the GDL in the fifteenth century is an exaggeration, but in general his remarks about the equipment of the knight in the genesis of knighthood are reasonable; see Antanaitis, 'Riterijos apraiška Lietuvoje', pp. 128-129. 
(German Ritter, French chevalier, Spanish caballero), and in some contexts it could be used slightly differently, for example, in the early medieval period miles Christi was a 'soldier of Christ', a martyr. Between the eleventh and thirteenth centuries, at the time chivalry flourished, an entire complex of rituals, images and norms developed, thus forming the concept of the knight and significantly affecting the world outlook of both the kings and ordinary bearers of arms in Western Europe. The Church played a crucial role in the process of the formation of the ethics of knighthood. At that time any soldier who went through a certain ritual of initiation and held knightly values could be called a 'knight'. Later the term knighthood was applied to the lesser gentry, although the idea of knighthood remained a universal feature in the self-consciousness of medieval aristocracy. ${ }^{12}$ Therefore, the division of knighthood into service, title, estate and idea, proposed by Werner Paravicini is possibly quite valid. ${ }^{13}$

The transformations of European knighthood proceeded in several directions in the Middle Ages. Firstly, the social process of knighthood was complete: from the thirteenth century only a person of knightly origin could be dubbed a knight. On the other hand, this circumstance partly conditioned the differentiation of knighthood proper. Formerly one's knighthood did not depend on one's birth - anybody could become a knight after a certain ritual. After the establishment of the principle of the heritage of 'the knightly estate' the formal knighting ceremony actually became redundant. Since this ceremonial was conducted at comparatively great expense and the corresponding occasions became rarer (the era of the crusades was over, some of the nobility preferred not to do their military service, etc.), the majority of the middle and lesser gentry did not seek the ceremonial of dubbing. This ritual gradually became an attribute presented by the nobility on particular occasions. Such representatives of the nobility usually did not call themselves knights, but in the phraseology of scribes and chroniclers a new term appeared - 'knights admitted to an order' thus accentuating the prestige difference between the two groups of

${ }^{12}$ On the development of the medieval knighthood, see Das Rittertum im Mittelalter, ed. A. Borst (Darmstadt, 1976); J. Fleckenstein, Vom Rittertum im Mittelalter. Perspektiven und Probleme (Goldbach, 1997); M. Keen, Chivalry (New Haven-London, 2000); and the most recent work J. Ehlers, Die Ritter. Geschichte und Kultur (Munich, 2006).

${ }^{13}$ W. Paravicini, Die ritterlich-höfische Kultur des Mittelalters, 2nd ed. (Munich, 1999), p. 3. 
knights. Consequently, these developments resulted in a paradoxical situation: the nobility continued to propagate knightly values, meanwhile the concept 'knighthood' remained a characteristic of the lesser gentry. Therefore, in the interpretation of the sources of the late Middle Ages the two aspects of knighthood should be kept apart: an individual knight inducted into an order and a pluralistic estate characteristic of knighthood.

Although the Late Middle Ages saw the end of knighthood, ${ }^{14}$ certain signs of its 'renaissance' were obvious, too; and they conditioned the transfer of this idea to the early new times. Knighthood was the motive that made the noblemen of Europe conduct campaigns against the pagan Lithuanians in the fourteenth century and organise crusades against the Turks in the fifteenth century. Establishing orders of knighthood of a new type, Western European monarchs availed themselves of the idea of knighthood and only attached loyalty to the lord in addition to traditional knightly virtues. Finally, in the latter half of the fifteenth century a new knighthood movement began among the lesser gentry, leading to the massive formation of the institutions of knighthood. Their aim was to defend their positions in the circumstances of the political and social expansion of the rulers and burghers of the state. ${ }^{15}$

In this period knightly culture began to spread in central and eastern Europe. Although induction into knighthood had been known since the early Piast times, knighthood customs in Poland actually began to develop only in the times of Casimir the Great - in the midfourteenth century. ${ }^{16}$ In Polish historical literature the concept 'knight' (as the opposite of szlachta) is used to denote the early noble stratum. ${ }^{17}$ However, the contemporary use of the terms must be taken into account: the Latin miles does not yet mean that the Polish

${ }^{14}$ J. Huizinga, Herfsttij der middeleeuwen (Haarlem, 1919).

15 A. Ranft, Adelsgesellschaften. Gruppenbildung und Genossenschaft im spätmittelalterlichen Reich (Sigmaringen, 1994).

${ }^{16} \mathrm{Cf}$. comprehensive works on knightly culture in Bohemia and Poland: W. Iwańczak, Tropem rycerskiej przygody. Wzorzec rycerski $w$ piśmiennictwie czeskim w XIV wieku (Warsaw, 1985); D. Piwowarczyk, Obyczaj rycerski w Polsce późnośredniowiecznej (Warsaw, 1998); B. W. Brzustowicz, Turniej rycerski w Królewstwie Polskim $w$ późnym średniowieczu i renesansie na tle europejskim (Warsaw, 2003).

17 Z. Wojciechowski, Prawo rycerskie w Polsce przed statutami Kazimierza Wielkiego (Poznań, 1948); K. Buczek, 'Prawo rycerskie i powstanie stanu szlacheckiego', Przeglad Historyczny, 69 (1978), pp. 23-44. 
nobleman referred to as such was ceremoniously inducted into knighthood in the Western sense of the word. Therefore, it is no accident that the German loan-word rycerz appeared in Polish at the same time when the ceremony of induction spread in the country in the second half of the fourteenth century. ${ }^{18}$ The concept of the knight has been discussed in Polish historiography at great length. Noteworthy are the statements of Janusz Bieniak and Ambroży Bogucki about a fundamental difference between miles strenuus 'dubbed knight' of the fourteenth and fifteenth centuries and the old miles. ${ }^{19}$ This difference arose under the influence of foreign chanceries. Worth mentioning is Henryk Samsonowicz's remark that the knighting ceremony and the knight's status actually did not affect the existing social situation, since only young men of noble birth could become knights; therefore it would be pointless to speak about a separate knightly grouping in legal terms. ${ }^{20}$ On the other hand, this statement does not account for the enormous popularity of the knighting ceremony with the Polish nobility and becoming a part of its titles at least for some time. The social situation of the nobility is revealed not only by the legal assessment of its representatives. The categories of honour and prestige are no less important in establishing the selfconsciousness and social status of this social stratum. Namely, the concept of knighthood is the expression of this second group of categories. The same could be said about the nobility of the Grand Duchy of Lithuania in the Late Middle Ages.

\section{Knighthood Culture in the Court of the Grand Duke of}

Lithuania In 1447 on the eve of his coronation in Poland Casimir IV Jagiellonian issued a privilege to Lithuanian noblemen, among other things, permitting them to go abroad to gain knowledge of knighthood there. This article of the privilege does not mean that previously the Lithuanian gentry did not have this right; rather it

18 A. Bogucki, Polskie nazwy rycerstwa $w$ średniowieczu. Przyczynki do historii ustroju społecznego (Włoclawek, 2001), pp. 67-68, 81.

${ }^{19}$ J. Bieniak, “Milites” w procesie polsko-krzyżackim z 1339 roku', Przeglad historyczny, 75 (1984), pp. 503-513; A. Bogucki, 'Strenuus jako tytuł polskich rycerzy pasowanych (XIII-XV w.)', Przeglad historyczny, 77 (1986), pp. 625-648; Bogucki, 'O pasowaniu na rycerza i grupach prawnych', Roczniki historyczne, 65 (1999), pp. 195-210; Bogucki, Polskie nazwy.

20 Samsonowicz, 'O rycerzach, giermkach i gościach', $R H, 63$ (1997); id., 'Jeszczie o pasie rycerskim, giermkach i klientach', $R H, 65$ (1999), pp. 211-214. 
marked the beginning of the takeover of the European travelling tradition in Lithuania. This tradition was comparatively new in Europe proper, and since the fifteenth century it had been spreading in Poland. $^{21}$ The documentation of such knighthood training travels was scarce in Western Europe, too. ${ }^{22}$ Thus, a collection of letters of indemnity and presentation of the Castilian knight Alfonso Mundarra, who visited Vytautas' court in 1412, is valued as one of the first of such documents. Therefore, it is astonishing that a customary corpus of European travels of the courtier of Casimir IV and future court treasurer of the GDL Alexander Soltan goes back to the years 14671469. ${ }^{23}$ These documents show that one of the motives for the journey was knighthood, and, according to the Paravicinis, Soltan was presumably knighted in the Holy Land in $1468 .{ }^{24}$ King Edward IV of England awarded the traveller a gold chain of the court (aureus torquis) as a token of appreciation, and the duke of Burgundy Charles the Bold bestowed on him the honorary titles of chamberlain and counsellor (in consiliarium et cambellanum nostrum retinendum duximus ). ${ }^{25}$ The letters of indemnity and presentation of the nobleman remained en bloc in the archive of his progeny. Data that are more extensive go back to the sixteenth century when such long trips acquired the character of studies and became a necessary element of young noblemen's education. ${ }^{26}$ Meanwhile in the fifteenth century such journeys were rare, and lessons of knighthood had to be learnt at home.

${ }^{21}$ H. Polaczkówna, 'O podróżnikach średniowiecznych z Polski i do Polski', Miesięcznik heraldyczny, 16 (1937), pp. 65-72, 126.

22 W. Paravicini, 'Fürschriften und Testimonia'

${ }^{23}$ R. Trimoniene, 'Vakaru Europos valdovų rekomendaciniai raštai Lietuvos didžiojo kunigaikščio Kazimiero dvariškiui. Aleksandro Soltano politinès veiklos štrichai', Lietuvos istorijos studijos, 3 (1996), pp. 101-119; A. und W. Paravicini, "'Alexander Soltan ex Lithuania ritum grecorum sectans". Eine ruthenisch-polnische Reise zu den Höfen Europas und zum Heiligen Land 1467-1469', Zwischen Christianisierung und Europäisierung: Beiträge zur Geschichte Osteuropas in Mittelalter und Früher Neuzeit. Festschrift für Peter Nitsche zum 65. Geburtstag, eds E. Hübner, E. Klug, J. Kusber (Stuttgart, 1998), pp. 367-401.

${ }^{24}$ A. und W. Paravicini, 'Alexander Soltan', p. 391.

${ }^{25}$ Ibid., pp. 387-388, The Paravicinis warned that that chain could not be mixed with the Order of the Garter and also emphasised that Soltan was not inducted into the Burgundian Order of the Golden Fleece. Those were institutional court orders, accompanied by a formal admission ceremony, ibid., pp 395-396.

${ }^{26}$ H.-J. Bömelburg, 'Adelige Mobilität und Grand Tour im polnischen und litauischen Adel (1500-1700)', Grand Tour, pp. 309-326. 
The investigation of the early manifestations of knighthood in Lithuania reveals that concrete names and descriptions of definite situations are rather rare. That is doubtless due to the quality and status of sources. Local chronicles, which are an important source for the reconstruction of the knightly way of life in other countries, were only rudimentary in Lithuania at that time. Information is found mainly in the texts of the chroniclers of the neighbouring states and in the correspondence of the GDL rulers and nobles (despite its regrettably limited scope). The majority of information relating to Lithuania is extant in the efficiently organised archive of the Teutonic Order. However, the fact that the Order was still a centre of knighthood culture at least in the first half of the fifteenth century makes the researchers be mindful of their reliability. The Order's influence in the reception of knightly customs was enormous; nevertheless the bias of such sources can distort the way research is carried out.

Incidental references show that the ceremonial induction into knighthood was an important event in the life of Vytautas' court. ${ }^{27}$ There are no descriptions of this ceremonial, but there are indications about the practising of this essential form of knightly culture at the court. The most notorious example is the knighting in Trakai in 1413 of Benedict Makra, envoy of Sigismund, king of the Romans, sent to resolve a dispute between Lithuania and the Order. This case became well known as it attracted a scandal. The superiors of the Order regarded this gesture by Vytautas as an attempt to win the arbiter's sympathy and lodged a protest. The Order's letter reveals some details of the ceremony: Vytautas presented the new knight with the main attributes - a gilt belt and spurs. ${ }^{28}$ Girding a gold or gilt sword (cingulum militare, balteum militare) was the focus of the dubbing ceremonial and a sign of knighthood. ${ }^{29}$ An alleged 'induction into

27 Petrauskas, 'Didžiojo kunigaikščio institucinio dvaro susiformavimas Lietuvoje (XIV a. pabaigoje - XV a. viduryje)', Lietuvos istorijos metraštis 2005/1 (Vilnius, 2006), pp. 5-38.

${ }^{28}$ Codex epistolaris Vitoldi magni ducis Lithuaniae 1376-1430 (CEV), ed. A. Prochaska (Cracow, 1882), p. 256: ...do sluck her in vor dem tische czu ritter und begobete in mit vorgolthen gorteln, spornen, schouben und andern kleinoth.

${ }^{29}$ Most probably such a belt (cingulum aureum) is referred to in the lawsuit of Vytautas' court in which the grand duke's nephew, Mykolas Žygimantaitis, put the blame on Jogaila's court marshal knight Zaremba for the theft of a gold belt. See Vitoldiana. Codex privilegiorum Vitoldi magni ducis Lithuaniae 1386-1430, ed. J. Ochmański (Warsaw-Poznań, 1986), p. 188. 
knighthood' is described at Vytautas' court. The grand master's jester, Henne, having arrived for a military campaign in 1427, treated the blow struck on him by Vytautas with a stick as a sign of knighting and required adequate respect. Henne's joke doubtless parodied the dubbing ceremony sometimes performed on the battlefield. It is also worth noting that in his letter to the grand master Vytautas used the terms of the knighthood ceremonial as a matter of course. ${ }^{30}$ That the campaigns against Pskov and Novgorod in 1426 and 1428 were not only military and political actions but also a form of knightly life is attested unequivocally by Vytautas' letter to the Livonian Order in 1426. In it the grand duke asked the master to allow Livonian knights and squires (ritter und knechte) of their own free will to join in the forthcoming raid 'for the sake of knighthood and other matters' 31 Knighthood rituals are mentioned by Jan Długosz - during the Novgorod campaign the Pole Wincenty of Szamotuły had the honour to carry the standard of St George, the patron saint of knights. ${ }^{32}$ Already since 1399 the campaigns led by Vytautas against the Tatars and the Orthodox had been organised as a way of exploiting the idea of knighthood for political aims. ${ }^{33}$ This practice, enforced by the generosity of the Lithuanian ruler, made his court a new centre of knightly culture and a sojourn in the journeys of the nobility in Europe. Thus Vytautas' Muscovite campaign of 1406 was attended by heralds from Holland and Burgundy ${ }^{34}$ - they had included the court of the grand duke of Lithuania into the communication network of European heralds. The heralds of the dukes of Brabant and Milan ${ }^{35}$ as well as the Tyrolean herald Rudolf Tyrol ${ }^{36}$ paid visits to Vytautas' court in 1420.

${ }^{30}$ On Henne's 'induction into knighthood' in 1427 (czum ritter geslagen), see CEV, p. 775. Henne's arrival for another campaign in 1428 is interpreted ironically by Vytautas as a wish 'to improve his knighthood' (noch der besserunge seiner ritterschaft), ibid., p. 801.

${ }^{31}$ Ibid., p. 732: '...umb ritterschafft adir umbe andir sachin wellen'.

32 Joannis Dlugossii, Annales seu cronicae incliti Regni Poloniae. Liber decimus et liber undecimus (1406-1412), ed. D. Turkowska (Warsaw, 1997), p. 246.

${ }^{33}$ Cf. S. C. Rowell, 'Lietuva - krikščionybès pylimas? Vienos XV amžiaus ideologijos pasisavinimas', Europos ideja Lietuvoje: istorija ir dabartis, ed. D. Staliūnas (Vilnius, 2002), pp. 17-32.

${ }^{34} \mathrm{CEV}$, p. 970.

${ }^{35}$ Liv-, Est- und Curländisches Urkundenbuch (LUB), ed. F. G. Bunge, vol 5 (Riga, 1867), p. 616; CEV, p. 463.

36 J. Caro, 'Liber cancellariae Stanislai Ciołek', Archiv für österreichische Geschichte, 45 (1871), pp. 475-476 (Vytautas' undated letter to the duke of Tyrol). 
The fact that the ceremonial of dubbing was practiced widely in Vytautas' court is attested by documents in which the title strenuus (German strenger) is constantly used with the names of some noblemen and boyars of Vytautas. According to the Order's sources, in 1405-1409 the ritual of dubbing was presided by Vytautas' herald Nicklus Luczke in the grand duke's court. ${ }^{37}$ The office of the herald at the court was institutional; there is a document showing that Vytautas appointed Jonas as his new herald conferring on him the land title Litherland. The custom to call heralds by the names of their countries was common in the courts of European rulers as well as in Poland where royal heralds had been known since $1395 .^{38}$ The importance of the herald's office is emphasised by its continuity in the times of Švitrigaila and Žygimantas Kęstutaitis (1430-1440). ${ }^{39}$

One of the earliest actions of the Lithuanian herald is related to a rare event in knightly communication. In 1403 a group of Lithuanian nobles sent a herald to the Brandenburg commander Markward von Salzbach to demand satisfaction for his insult of Vytautas. ${ }^{40}$ The combat had to take place according to the rules of knights (six combatants on each side) during the meeting on the border at the Dubysa River. The fight did not take place for procedural reasons which remain quite unclear. True, these conflicts often ended in this manner in many other cases, since the very symbolic challenge rather than the real fight was important in such quarrels. Despite open hostility, the officers of the Order and the Lithuanian dukes and noblemen shared the same values of knightly culture. That is also attested by the following facts: in the same year the Balga commander sent symbols of knighthood - spurs - to Manvydas and Čupurna ${ }^{41}$

${ }^{37}$ CEV, pp. 969, 972, 973 (Niclus Luczke des herczogen Witouts herolde).

38 S. K. Kuczyński, 'Heroldowie króla polskiego', Venerabiles, nobiles et honesti (Toruń, 1997), pp. 329-339. On Jonas Litherland, see. ibid., p. 334-335. The undated document of Vytautas has been preserved in a later collection of formularies (Vitoldiana, p. 188).

${ }^{39}$ See Petrauskas, 'Institucinio didžiojo kunigaikščio dvaro susiformavimas Lietuvoje'.

${ }^{40}$ Codex diplomaticus Prussicus (CDP), ed. J. Voigt, vol. 6 (Königsberg, 1861), pp. 174-175: '...bayoren herolden santen czu Marquard'. See also Johann von Posilge, 'Chronik des Landes Preussen', Scriptores rerum prussicarum, eds T. Hirsch, M. Töppen, E. Strehlke, vol. 3 (Leipzig, 1866), p. 267 (according to the chronicler, Vytautas was against the duel). Cf. A. Nikžentaitis, 'XIII-XIV a. lietuvių kariuomenès bruožai', p. 30.

${ }^{41}$ CDP, vol. 6, p. 174: 'czween par spornen umbe alder fruntschat willen'. 
in the name of old friendship and after some time various knightly attributes to Vytautas, too. ${ }^{42}$

In the late Middle Ages knightly combats or duels became a kind of knight tournament. At Jogaila's court tournaments were part of every major festivity. Doubtless, Lithuanian noblemen also participated in them. ${ }^{43}$ They attended tournaments held in other neighbouring countries as well. Dlugosz refers to Lithuanian knights as participants at one of the biggest early-fifteenth-century jousting tournaments held by Sigismund of Luxembourg on the occasion of the meeting of rulers in Buda in 1412.44 That Vytautas' court could have been an arena of jousting is attested by the 1422 letter of the Polish nobleman Jan Głowacz of Oleśnica to the Silesian knight Konrad in the service of the Order. In the letter the Polish nobleman challenged Konrad to a duel and proposed Vytautas' court as a possible site. Details about the ladies who were to watch the tournament and the proposal to organise a bigger jousting contest disclose the motives of the duel. ${ }^{45}$

Various forms of knightly culture became known in Lithuania in the aftermath of the visits of the knights from other countries that stayed for shorter or longer periods at the court of the grand duke. They could be envoys of foreign rulers, knights arriving for upcoming campaigns, or ordinary visitors as in the case of the aforementioned Castilian knight Alfonso Mudarra. ${ }^{46}$ Foreign knights were the principal propagators of knighthood in all central and eastern European countries. ${ }^{47}$ The reception of noble knights, such as the Burgundian

${ }^{42}$ In 1408 the master of the Order sent Vytautas 3 rittersatel, 3 ritterzome, 3 stegereyfen (three knight saddles, three bridles and three stirrups). Das Marienburger Tresslerbuch der Jahre 1399-1409, ed. E. Joachim (Königsberg, 1896), p. 489.

43 Regrettably, Długosz alluding to these tournaments very rarely refers to concrete circumstances, participating persons, etc. See S. Jakubczak, 'Elementy ludyczne w Długoszowych opowieściach o uroczystościach dworskich', Poznańskie Towarzystwo Przyjaciót Nauk. Wydziat nauk o sztuce. Sprawozdanie, 102 (1984), pp. 12-18; Brzustowicz, Turniej rycerski, pp. 244-255.

44 Dlugossii, Annales... (1406-1412), p. 202.

${ }^{45}$ CEV, p. 578. Cf. Piwowarczyk, Obyczaj rycerski, pp. 169-171.

${ }^{46}$ Paravicini, 'Fürschriften und Testimonia', pp. 903-936; Rowell, 'Du Europos pakraščiai', pp. 149-188.

${ }^{47}$ E. Fügedi, J. M. Bak, 'Fremde Ritter im mittelalterlichen Ungarn', Quaestiones Medii Aevi Novae, 3 (1998), pp. 3-17; T. Jurek, 'Fremde Ritter im mittelalterlichen Polen', ibid., pp. 19-49. 
knight, envoy of England and France, Ghillebert de Lannoy in 1413/ 1414 and 1421 who left his memoirs of those events, ${ }^{48}$ was an occasion to renew the ties of friendship with the rulers of other countries and to demonstrate the prestige of the ruler among the local population. Foreign knights coming with superior equipment were an important force in the battles and a social support in the service of the court. Quite a number of those who came for some campaign stayed for some time in the ruler's milieu, and some even received offices at the court. The Pole Jakub of Kobylany, renowned for his knighthood, became Vytautas' court marshal, and the court treasurer was the Mazovian knight Jerzy Strumilo. Some of Vytautas' clerks of noble birth were knights, too. ${ }^{49}$ Many of those in the service of Vytautas possessed lands in Poland. Thus in 1429 in his letter to the master of the Order, Vytautas mentioned the Polish knight (strenger ritter) Sestrenec, who served at his court and at the same time had lands in Poland. ${ }^{50}$

In addition to Poland and the Teutonic Order, the reception of knighthood was greatly influenced by Silesia, then part of the Holy Roman Empire. The disunity of this country, balancing against the interests of Germany, Bohemia and Poland, conditioned the loss of its political power and led to the rise of a great number of ducal estates. Therefore in central and eastern Europe Silesia became a region of the most intensive development of knighthood. In the first half of the fifteenth century the contacts between Silesia and the GDL were unusually close. Vytautas' long-time attendant was the Silesian knight Conrad Frankenberg. ${ }^{51}$ Another knight from Silesia was Thomschik von Tannenfeld, who served Vytautas during his wars against the Order in 1410 and 1422 and went on diplomatic missions for him. In 1410 Vytautas appointed him starosta in the occupied castle of Elbing ${ }^{52}$, and in 1412 sent him to the Bohemian

${ }^{48}$ P. Klimas, Ghillebert de Lannoy. Dvi jo kelionès Lietuvon Vytauto Didžiojo laikais (1413-1414 ir 1421 metais) (Kaunas, 1931).

${ }^{49}$ For example, the scribe Nikolai Sepienski was named 'a knight' in 1427, CEV, p. 770.

${ }^{50}$ Ibid., p. 839.

${ }^{51}$ In 1413 strenuus Conradus Frankenberg miles (Lites ac res gestae inter Polonos Ordinemque Cruciferorum, vol. 2 (2nd ed.), ed. I. Zakrzewski (Poznań, 1892), p. 146), unser ritter Conrad Frankenberg (CEV, p. 192).

${ }_{52}$ M. Pelech, 'Die Auseinandersetzung zwischen dem schlesischen Ritter Thomschik von Tannenfeld und dem Deutschen Orden nach dem großen Krieg von 1410-1411', Beiträge zur Geschichte Westpreußens, 11 (1989), pp. 87-106. 
king. ${ }^{53}$. The group of companions brought by Thomschik from Silesia in 1410 comprised the knight Sigmunt Roth, who later functioned as a trustee of Vytautas and Svitrigaila in their contacts with the emperor of the Holy Roman Empire. ${ }^{54}$ In 1417 Duke Conrad the White of Oleśnica, previously having served the Order, was mentioned among Vytautas' courtiers. ${ }^{55}$ In 1428 Vytautas' court played host to one of the most active propagators of knightly culture in the region Duke Ludwig of Brzeg and Legnica in Silesia. ${ }^{56}$ His knighthood pursuits were promoted by his kinship ties in Burgundy - his aunt was the mother of Philip the Good, duke of Burgundy, and by his frequent journeys to foreign countries, including the Holy Land. His personal contacts are attested by the trip of Ludwig's envoys to Švitrigaila during the conflict with the Poles in $1432^{57}$ as well as by the appearance of several Silesian dukes and noblemen in Švitrigaila's environment. ${ }^{58}$

Foreign knights were the propagators not only of knightly symbols and new weapons but also of various other novelties, as is attested by a Bohemian knight who lived at Vytautas' court and defended Jan Hus' teaching at the time of the Council of Constance. ${ }^{59}$

The knightly self-consciousness of these newcomers is illustrated by the case Vytautas' courtier Jerzy Strumilo. This Mazovian noble

53 GStA PK, OBA 1674.

${ }^{54}$ Pelech, 'Die Auseinandersetzung', p. 101 (document of 1411 containing a list of Silesian knights).

${ }^{55}$ Dux Conrad Albus aulicus noster (A. Liedtke, 'Nieznany list W. Księcia Litewskiego Witołda do Jana biskupa włocławskiego z r. 1417', Kwartalnik Historyczny, 46 (1932), p. 149; CEV, p. 396).

56 Preclarus Loduigus dux Slesie (Vitoldiana, p. 102). More on him, see F. Szafrański, Ludwik II brzesko-legnicki (Wrocław, 1972).

57 Scriptores rerum silesiacarum, vol. 6, ed. C. Grünhagen, (Breslau, 1871), p. 120.

58 Niclos Schellendorffer (diner, erbarer und wolgeborener Nicclos Schellendorfer us der Slesie lieber getruwe) was Švitrigaila's envoy to the Order at the end of 1432 (GStA PK, OBA 6236, 6701). The representatives of the Schellendorffer family were the nearest noblemen of Duke Ludwig (F. Szafrański, 'Stosunki narodowościowe i społeczne dworu brzesko-legnickiego w pierwszej połowie XV wieku', Acta Universitatis Wratislaviensis. Historia, 14 (1968), pp. 5981. In the same year Duke Wenczlaw of Opawa (Troppau) was referred to Švitrigaila's courtier (Wenczlaw von Troppau unser hoffgesinde und lieber getruwe) (GStA PK, OBA 6124).

59 In his letter of 16 May 1417 the bishop of Dorpat asked Vytautas to punish that knight for heresy (ein bemesch ritter de iweren hope), CEV, p. 382. 
made an impressive career, and at the end of Vytautas' life he even became the court treasurer. ${ }^{60}$ After Vytautas' death he settled at the border of Mazovia, the GDL and the Order and often came into conflict with the Order's officials. ${ }^{61}$ One of the clashes was directly related to a matter of knightly honour. In a letter of June 1432 the representative of the Order in Grodno wrote to the master about Strumilo's quarrel with the lieutenant of Lyck who called Strumila 'an infamous knight' (untuchtiger ritter) and this remark offended him deeply. ${ }^{62}$ The Order's agent asked the master to smother up the scandal, damaging good relations between the two sides. Subsequently Strumilo moved to Poland and continued to use the title of the knight. ${ }^{63}$

There is less information about foreign knights in Lithuania and about knighthood in general from the latter half of the fifteenth century. Knighthood culture became a part of international contacts of the GDL nobility. Lithuanian noblemen gradually became involved in the revived crusading movement. Already in the fourth decade the Volhynian nobleman Piotr of Kremenec used an untypical title 'knight of God' (Божий рытерь), ${ }^{64}$ the possession of which could signify both the participation in the campaigns against the Turks and the dubbing ceremony during a pilgrimage to the Holy Land. In 1482 Pope Sixtus IV addressed his breve about the organisation of a crusade against the Turks to the palatines of Vilnius and Trakai Alekna Sudimantaitis and Martynas Goštautas. ${ }^{65}$ In 1484 the starosta of Žemaitija Jonas Kęsgailaitis stated in his letter to the master of the Order that if necessity arose he was ready to take part in the master's campaign against the heathens, since Christianity was severely weakened and that process had to be stopped. ${ }^{66}$

${ }^{60}$ On his life and political career, see S. Jakubczak, 'Jerzy Strumiłło przywódca konfederacji lwowskiej 1464 roku’, Społeczeństwo Polski średniowiecznej, 5 (1992), pp. 245-254.

${ }^{61}$ GStA PK, OBA 5658, 6119, 6427, 6438, 7000, etc.

62 GStA PK, OBA 6119.

${ }^{63}$ Bogucki, 'Strenuus jako tytuł', p. 633.

${ }^{64}$ Lietuvos Metrika. Užrašymu knyga 3, comps L. Anužytė and A. Baliulis (Vilnius, 1998), p. 63.

65 Elementa ad fontium editiones, 64: Brevia Romanorum Pontificum ad Poloniam spectantia (vol. 1: Brevia saeculi XV), ed. H. D. Wojtyska CP (Rome, 1986), p. 52.

${ }^{66}$ GStA PK, OBA 17114: 'Got weis von himel, wen es kweme, das ewer groszmeichtikeit solde czin kein dy hadenschoft, wir welden selbest ewer wirdikeit gerne dinen, wen doch dy kristenheit leider genuck geswecht wirt und man sy nicht forder dorften swechen'. 
At that time knightly rank could be obtained only abroad, while previously induction into knighthood had been conducted at the court of the grand duke as well. The ruler's marshal, Stanislovas Sudijovaitis, was knighted in Rome in 1469 and his clerk Jonas Sapiega in 1501 - they first appeared with those titles during the journey. ${ }^{67} \mathrm{As}$ indicated above, Alexander Soltan was knighted most probably in the Holy Land. It is also possible that Grand Duke Alexander's future favourite and court marshal Mikhail Glinski was inducted into knighthood during his lengthy journey through the courts of European rulers. Some noblemen became members of knightly communities founded by foreign rulers. This kind of activity was particularly developed by the emperor Maximilian I who possibly inherited this tradition from the duke of Burgundy. ${ }^{68}$ In 1518 Canon Laurentius Międzyleski of Vilnius bestowed the privilege to be inducted into 'gold knights' of the Empire (miles eques auratus) on six Polish, Mazovian and Lithuanian families (of the same coat of arms - Hawk/ Jastrzębiec); this right was granted by the emperor. The GDL was represented by two different branches of the same stock - the Nemirowiczes and Szczitowiczes. In contemporary Poland and Lithuania the title of 'golden knight' was still rather rare, and it was only later that this custom of knighting outstanding burghers became commonplace. ${ }^{69}$

In this connection Grand Duke Alexander's idea to establish a brotherhood of knights for the struggle against the Muscovites and pagans is worth noting. ${ }^{70}$ Until that time in Poland and Lithuania there were no attempts to found such orders, though some of the rulers and noblemen were members of the orders of the courts of other European monarchs. Thus, in 1408 Sigismund of Luxembourg, King of Hungary, had established his Order of the Dragon (the overpowered dragon is a symbol of Saint George, patron saint of knights) and in 1429 had admitted Vytautas and granted him a special

${ }^{67}$ Kodeks dyplomatyczny katedry i diecezji wileńskiej (henceforth - KDKW], comps J. Fijałek and W. Semkowicz (Cracow, 1932-1948), pp. 301, 568.

${ }^{68}$ On Maximilian I's court policy, see J.-D. Müller, Gedechtnus. Literatur und Hofgesellschaft um Maximilian I (Munich, 1982). On Maximilian's knighthood: Paravicini, Die ritterlich-höfische Kultur, pp. 108-112.

${ }^{69}$ Cf. T. Szulc, 'Eques auratus w dawnej Rzeczypospolitej', Acta Universitatis Lodziensis. Folia Iuridica, 38 (1988), pp. 59-97.

${ }^{70}$ A German document, written by Grand Duke Alexander of Lithuania in Minsk on 2 July 1500 about the establishment of a brotherhood of knights, J. Caro, Geschichte Polens, vol. 5/2 (Gotha, 1888), Analekten, pp. 1022-1024). 
privilege to enrol new members from the nobility of the GDL. ${ }^{71}$ Alexander Jagellonian's initiative should be regarded as the only endeavour of this kind in Poland-Lithuania, a rather late imitation of knightly culture. In his letter addressed to foreigners in 1500, Alexander, supported by his subjects, declared his intention to establish a brotherhood of knights (ein ritterliche bruderschafft) with whose aid he expected to take up a successful struggle against the dukes of Muscovy and 'other infidels'. In order to broadcast this information more widely, he sent his courtiers (unser hoffgesind) Jost Dracula and Maciej Steczko. Although there is no information about the fate of this endeavour, ${ }^{72}$ the document about the invitation of knights throws light on personal relations between the ruler and mercenary courtiers that were based not only on financial obligations but also on universal knighthood categories.

\section{The Term Miles Strenuus in the GDL in the Fifteenth Century}

Sources from the late fourteenth and fifteenth centuries do not contain any descriptions of the dubbing of Lithuanian nobles. Długosz recounts that on the eve of the Battle of Grunwald (Žalgiris) Jogaila knighted a number of soldiers. This information is confirmed by other sources; however, the event is not specified by the Polish chronicler. Therefore, the only possibility to determine the use of the title and the spread of the phenomenon of knighthood in the GDL is the analysis of the titles Lithuanian nobles found in the documents and letters. In Polish scholarship this method was successfully exploited by Bogucki, who noticed a regular use of the Latin strenuus to designate the knighted warrior. ${ }^{73}$ In the documents of the GDL of the fifteenth and early sixteenth centuries this title is also fairly frequent, and therefore the exact use of this rather unspecific Latin word must be examined.

A review of the fifteen-century sources suggests some conclusions. Certainly, the reflection of all the uses of the title cannot

${ }^{71}$ Regesta imperii, vol. 11 (Innsbruck, 1896-1900), no. 7352. Interestingly, Vytautas" wife Julijona was also a member of this order - in addition to Sigismund's wife she was the only woman honoured with this knighthood; Ritterorden und Adelsgesellschaften im spätmittelalterlichen Deutschland. Ein systematisches Verzeichnis, eds H. Kruse, W. Paravicini, A. Ranft (Frankfurt am Main u. a., 1991), pp. 240-241.

72 Alexander again returned to this idea in May 1503 preparing a new Erasmus Ciolek's mission to the pope; Akta Aleksandra, ed. F. Papée (Cracow, 1927), pp. 281-282).

${ }^{73}$ Bogucki, 'Strenuus jako tytuł'. 
be expected, but it is important to reveal the main tendencies. Research is not confined to Latin texts, since the German title strenger (gestrenger) had the same meaning. Ruthenian texts are few; nevertheless, they are valuable as a testimony of the social and semantic reception, enabling the peculiarities of the local terminological perception. The most extensive data are found in the lists of witnesses in the documents of rulers, the Church, and nobility, where people were usually described in the terms of their titles and offices held. It is noteworthy that the use of titles in the then documents was extremely systematic. The following pattern was predominating: the persons' names were preceded by their titles and followed by the indication of their offices - strenuus et nobilis N. palatinus Vilnensis. Meanwhile the titles were usually not used in the documents of the nobility and gentry, and people were mostly defined in the terms of their origin: haeres, filius de. More problematic are contexts when the same title (e.g. strenuus et nobilis) is placed before a number of persons. In such cases it is best to attribute the first title to the first two persons in the list and to look for the endorsement of such interpretation in other sources, primarily in the correspondence of the ruler and nobility.

The titles strenuus and strenuus miles occurred frequently in Vytautas' documents. ${ }^{74}$ They were added to the names of nearly all distinguished noblemen of that time. ${ }^{75}$ The majority of Polish noblemen visiting Vytautas' court were also called strenui (milites). The list of the witnesses in Vytautas' donation to the starosta of Vilnius Albertas Manvydas (nobilis ac strenuus miles) in 1409 shows that the producers of the document deliberately separated the knighted persons: the name of the untitled court official was given after those of the knights. ${ }^{76}$ This practice is confirmed by Vytautas' German letters in which the Latin strenuus was replaced by the German strenger ritter. Some, possibly famous for their knighthood, were referred to as 'the most renowned knights' (namhaftiger ritter). ${ }^{77}$ At the end of Vytautas' rule there was a growing tendency to call the noblemen magnificus and to omit the indication of their knighthood. In the document of 1452 Magdalena Jagint called herself the widow of the

${ }^{74} \mathrm{Cf}$. documents in CEV, KDKW, LUB and Vitoldiana.

${ }^{75}$ See the appendix to this article.

76 Vitoldiana, pp. 73-74.

77 Cf. strenger ritter Kinsgail (CEV, p. 699) or namhaftiger ritter (GStA PK, OBA 6095, 6114). For more examples, see the Appendix. 
knight Jagintas (relicta strenui domini Jagint) and issued her message with her three sons' approval. It is noteworthy that the first two sons were explicitly called knights (strenuo milite domino Rimouid et strenuo domino Saczkone), while the third was simply described by the then generic name 'lord' (domino Michaele). ${ }^{78}$

However most interesting is Andrius Daugirdaitis' Ruthenian text, since it is accompanied by a Latin variant. In 1461 the last representative of the Daugirdases of the coat of arms of Pomian (not to be confused with other contemporary and subsequent Daugirdases) issued several documents for his servants and the Church before his death. All of them were written at the same time and their witnesses were the same persons. The comparison of the Latin and Ruthenian variants is essential for this study. The preparation of the Latin document was witnessed by strenuisque dominis Tholthvil et Vasgal, generosisque domino Iusko Czyszowicz, Conrado Hanuszkowicz. ${ }^{79}$ In the Ruthenian text the same persons were presented as при пасаных рытеров пана Яна Товтила а пана Вазкеила а вроженых пана Юшка Чыжевича а Кундрата Юшковича. ${ }^{80}$ Thus the word strenuиs was clearly perceived by the scribe as the equivalent of nacaнbl pыmep; and generosus, meaning only gentility, was translated as врожены. The word nacaнbl was a Polonism - since the late fourteenth century the knights, dubbed in the Polish manner, had been called pasany, i.e. 'engirded (with a knightly belt)' ${ }^{81}$ Thus, the distinction between two groups of nobles is obvious - inducted into knighthood and not inducted. The very placement of the knights at the top of the list does not yet speak about the social status of knighted persons. In the aforementioned case that place was conditioned rather by Tautvilas' origin. ${ }^{82}$ Nevertheless, this shows the dominating position of the nobility among the knights and the prestige of the knight's rank in the Lithuanian aristocracy.

The data collected reveal certain peculiarities of the use of the knight title. Persons bearing this title were found most frequently in

${ }^{78} \mathrm{KDKW}$, p. 240 (donation to the Franciscans of Vilnius).

${ }^{79}$ Ibid., p. 273 (donation to the Cathedral of Vilnius).

${ }^{80}$ Lietuvos valstybès istorijos archyvas, f. 525, ap. 8, b. 395, fo. 18 (donation to the servant Jurcza). I am grateful to Laimontas Karalius for drawing my attention to this source.

${ }^{81}$ Bogucki, Polskie nazwy rycerstwa, p. 88.

${ }^{82}$ He doubtless was identical to Jonas Tautvilas Mantautaitis, born into an influential Mantautas family; Petrauskas, Lietuvos diduomene, p. 263. 
the documents and correspondence of Vytautas' time, and that enlarged the knowledge about the spread of knighthood in the GDL. Vytautas' court was the principal disseminator of knighthood customs and the way of life. That was stipulated by Vytautas' personal interest in this culture and the contemporary tendencies of the European gentry. Foreigners surrounding the grand duke and the local nobility forged their own knightly identity by practicing the ceremonials of dubbing. Thus, the Lithuanian nobility rapidly took over the European norms and world-view, and that conditioned its radical transformation in the fifteenth and early sixteenth centuries. ${ }^{83}$ Rallying the knightly community in his court Vytautas was concerned not only with the reform of the army, primarily with the formation of equestrian troops (the policy of landownership served this purpose ${ }^{84}$ ) but also (and maybe in the first place) with the cultural affinity between the monarch and the nobility, not weakening the former's exceptional position. Therefore it would be possible to hypothesise that the induction of the most influential GDL nobles into knighthood (and namely only they were eligible for this rank) was a kind of substitute of the order of knighthood peculiar to the courts of European rulers. It was part of an essential Vytautas' reform - the integration of the representatives of the ruling elite at the ruler's court into various power structures. ${ }^{85}$

Meanwhile in social terms 'knighthood' and 'elevation to knighthood' were signs separating the nobility from the rest of the gentry. Although all nobles were eligible for knighthood, in reality only few people could be knighted due to various circumstances (the position at the court, the cost of the full representative equipment of the knight, etc.). Induction into knighthood did not mean any age of majority. Like elsewhere in late-medieval Europe persons distinguished in wars or in service were knighted. On the other hand, in the course of time, the nobility discovered new forms of distinction, and the concept of knighthood acquired a different social meaning. The nobles gradually stopped using this title or used it only occasionally in the

${ }^{83}$ Petrauskas, Lietuvos diduomene; idem, 'Titulas ir valdžia: Lietuvos Didžiosios Kunigaikštystės didikų savimonès pokyčiai XVI amžiaus pirmoje pusėje', Pirmasis Lietuvos Statutas ir epocha, ed. I. Valikonytė and L. Steponavičienè (Vilnius, 2005), pp. 35-46.

${ }^{84}$ E. Gudavičius, 'Lietuvių pašauktinès kariuomenès organizacijos bruožai', Karo archyvas, 13 (1992), pp. 43-118.

${ }^{85}$ R. Petrauskas, 'Ankstyvosios valstybinès struktūros Lietuvoje XIII amžiujeXV amžiaus pradžioje', Lietuvos istorijos studijos, 16 (2005), pp. 19-30. 
documents. Sometimes the terms 'knights' and knighthood' were used in the plural to refer to all men of noble birth capable of carrying arms and obliged of doing military service. ${ }^{86}$ Although that was also a result of the reception of knightly culture, it had little in common with its concrete manifestations. This estate category of knighthood contributed to the formation to the unanimous perception of the gentry estate and its final separation from the peasantry. However, it should be kept apart from the singular use of the concept 'knight' used to refer to a ceremonially dubbed person.

At the end of the fifteenth century, the forms of knighthood culture began to change. For some time the dubbing ceremonial was no longer practiced at the court of the grand duke. During Alexander's reign some traces of knighthood conception might be detected in the revived permanent court of the grand duke, ${ }^{87}$ but institutional forms of knighthood cannot be found anymore, excepting the aforementioned establishment of the ephemeral brotherhood of knights for the struggle against Muscovy. The office of the GDL herald vanished already in Casimir's time. Miles strenuus gradually disappeared from document testations in the latter half of the fifteenth century. This tendency coincided with that in Poland where the most intensive period of the induction into knighthood was also the end of the fourteenth and the first half of the fifteenth centuries. ${ }^{87}$ True, the knights (pыuepbl повылионы) were set apart in the First Lithuanian Statute. ${ }^{89}$ The appearance of a special Ruthenian term nacaubl instead of the Polonism attests to a further development of the conception of knighthood. Nevertheless, knightly culture was only a matter of interest of individual noblemen, such as the ruler's marshal Jonas Litavoras Chrebtavičius, emphatically titled strenuus miles in a document of

${ }^{86}$ For the first time it was clearly formulated in 1442 in Lietuvos Metrika. Užrašymu knyga 25, ed. D. Antanavičius and A. Baliulis (Vilnius, 1998), p. 186 and in the documents of 1447 .

${ }^{87}$ For example, in Grodno on 30 March 1500 Alexander's courtiers the brothers Bartosz and Jonusz Szwierczowski pledged 'on their word as knights" (verbo suo militari) to pay off their debt to the burgher of Cracow, Piotr Morsztyn (Account book of Alexander's court, Warsaw, Archiwum Główne Akt Dawnych, Rachunki Królewskie, sygn. 25, fo. 18v).

${ }^{88}$ Bogucki, 'Strenuus jako tytuł', p. 645.

89 Pirmasis Lietuvos Statutas, t. II/1: Tekstai senaja baltarusiu, lotynu ir senaja lenku kalbomis, ed. S. Lazutka, I. Valikonyte, E. Gudavičius (Vilnius, 1991), p. 62. Cf. also Gudavičius, Lazutka, 'Riteriai', pp. 108-109. 
Sigismund the Old in $1510,{ }^{90}$ duke Ilia of Ostrog, whose duel with the Polish nobleman Tęczyński is mentioned in a source in $1534,{ }^{91}$ or Jonas Hlebavičius the Younger who won in a tournament during a ducal wedding. ${ }^{92}$ In the first half of the sixteenth century and in particular in Sigismund Augustus' reign jousting tournaments became fashionable for some time as a favourite form of court games. ${ }^{93}$ Nevertheless, it was only a relic of knightly culture.

On the other hand, in the late Middle Ages the social sphere of knighthood became wider. Since Alexander's time burghers had been inducted into knighthood. It could be a way of honouring the town management on some festive occasion or a part of the procedure of raising some individuals to the rank of nobility. In Lithuania this combination of raising to some rank and dubbing was seen in 1525 , when Sigismund the Old honoured Michal Jozefowicz in this way. ${ }^{94}$ The phenomenon of knighthood, modified socially and culturally, survived into modern times. Knighthood customs and values were well known, but in the culture of the GDL they did not become a widespread phenomenon. This variance was noticed by Jüratè Kiaupiene, and she raised the question of its causes. This could be possibly accounted for partly by the limitation of the sphere (only the grand duke's court, in addition to a late reception), a narrow circle of a socially active knighthood, a certain gap in the tradition in the sixteenth century, conditioned by personal changes in the nobility of the GDL.

A generalised example of the Lithuanian noble knight could be Albertas Jonaitis Manvydas. Born into one of the most prominent families of the GDL nobility, and at that time possibly the only representative of that stock, most probably having spent his youth at the ruler's court, subsequently he did not make any brilliant political career despite his status and wealth and he hardly ever appears in the sources. His real interests may be disclosed by the sources of

90 Lietuvos Metrika. Užrašymu knyga 8, ed. A. Baliulis, R. Firkovičius, D. Antanavičius (Vilnius, 1995), p. 376.

${ }^{91}$ Acta Tomiciana, vol. 16/1 (Wroclaw, 1960), p. 603 (ein gut Rennen).

92 Wojciech Wijuk Kojałowicz, Herbarz rycerstwa W. X. Litewskiego tak zwany Compendium czyli O klejnotach albo herbach, ed. F. Piekosiński (Cracow, 1897), p. 135.

93 Brzustowicz, Turniej rycerski, pp. 286-302.

${ }^{94}$ Lietuvos Metrika. Užrašymu knyga 12, comps D. Antanavičius and A. Baliulis (Vilnius, 2001), p. 594: 'in militem et nobilem creavimus et nobilitavimus'. 
the Bavarian court, describing the wedding at Landshut in $1475 .{ }^{95}$ In this wedding ceremony he was a member of the escort of Jadwiga daughter of the sovereign of Poland-Lithuania, Casimir IV, who was to be married to Duke George of Bavaria. One exhaustive list of the guests shows that Manvydas arrived at the court of the Bavarian dukes with a retinue of 50 persons and that number distinguished them from other Polish noblemen in Jadwiga's escort and received the attention of the local nobility. In their accounts eyewitnesses of the ceremony, Weit Arnpeck and Ulrich Füter, spoke about 'a mighty Pole named Manvydas' (ein maechtiger Polack, genannt Monavit) and described his jousting duel with Duke Christopher of Bavaria (this event was described in other accounts of the wedding, too). The combat was won by the duke and he presented Manvydas with a tournament prize and a valuable charger. On his way back the Lithuanian nobleman fell ill and died, and his death meant the end of the Manvydas family. The fate of Albertas Manvydas the Younger is a reflection of the history of knighthood in Lithuania - he was a kind of 'the first and the last knight' of the GDL, who lived and died in the age of the demise of knighthood.

\section{APPENDIX}

\section{List of the Knighted Noblemen of the GDL (1400-1501)*}

Albertas Manvydas 1404, strenuus miles (CEV, p. 100); 1409, strenuus miles (Vitoldiana, p. 73); 1409, strenger bester ritther (GStA PK, OBA 1196); 1410, strenuus miles (KDKW, p. 78); 1421, strenuus miles (ibid., p. 741)

Mykolas Mingaila 1407, strenuus miles (Vitoldiana, p. 72); 1411, strenuus (KDKW, p. 86)

Stanislovas Čupurna 1407, strenuus miles (Vitoldiana, p. 72); 1409, strenuus miles (ibid., pp. 73-74); 1410, strenuus miles (KDKW, pp. 78, 83)

95 S. Hiereth, Zeitgenössische Quellen zur Landshuter Fürstenhochzeit (Landshut, 1959); M. Biskup, 'Wokół „Landshuckiego wesela“ 1475 roku', M. Biskup, K. Górski, Kazimierz Jagiellończyk. Zbiór studiów o Polsce drugiej połowy XV wieku (Warsaw, 1987), pp. 297-298.

* For biographical data of the knights, see Petrauskas, Lietuvos diduomene, pp. 214-309. The years mark the date when a particular person was mentioned with the indicated title. 
Rumbaudas Valmantaitis 1407, strenuus miles (Vitoldiana, p. 72); 1409, strenuus miles (ibid., pp. 73-74); 1415, strenuus (KDKW, p. 99); 1432, strenuus (ibid., p. 144)

Kristinas Astikas 1407, strenuus miles (Vitoldiana, p. 72); 1421, strenuus miles (KDKW, p. 741), 1431, namhaftiger und strenger herr (GStA PK, OBA 5636)

Talvaiša 1407, strenuus miles (Vitoldiana, p. 72)

Vidiminas 1408, strenuus (Vitoldiana, p. 151)

Sudimantas 1409, strenuus miles (Vitoldiana, pp. 73-74)

Jonas Sungaila 1409, strenger bester ritther (GStA PK, OBA 1196); 1423, strenger herr (LUB, vol. 7, p. 37)

Jurgis Galminas 1409, ritter (CEV, pp. 183-184)

Alekna Mangirdaitis 1410, strenuus miles (Vitoldiana, p. 30)

Mikita 1414, miles (Joannis Dlugossii Annales seu cronicae, lib. 11, p. 37)

Jaunius Valmantaitis 1415, strenuus (KDKW, p. 99); 1417, strenuus miles (ibid., p. 739)

Jonas Butrimas 1416, strenuus (Vitoldiana, p. 87); 1420, strenuus miles (Vitoldiana, p. 154). He is called 'a knight' (miles) by Długosz in 1414 (Joannis Dlugossii Annales seu cronicae, lib. 11, p. 37)

Petras Mangirdaitis 1416, strenuus (Vitoldiana, p. 87); 1431, strenger ritter (CEXV, vol 2, p. 256); 1433, strenuus dominus (KDKW, p. 147); 1436, strenuus (R. Jaworski, 'Z najdawniejszych dokumentów', p. 111); 1442, strenuus (KDKW, p. 193)

Mykolas Kęsgaila Valmantaitis 1417, strenuus miles (KDKW, p. 739); 1425, stenger ritter (CEV, p. 699); 1430, strenger (ibid., p. 921); 1447, gestrenger (GStA PK, OF 16, pp. 1184-1185)

Jurgis Gedgaudas 1418, miles (Bullarium, vol. 4, p. 61); 1420, strenuus miles (Vitoldiana, p. 154); 1430, strenuus (KDKW, p. 138); 1432, namhaftiger und strenger herr (GStA PK, OBA 6030)

Jurgis Strumila 1428, strenuus miles (Vitoldiana, p. 46); 14341437, strenuus (A. Bogucki, Strenuus jako tytuł, p. 633)

Jurgis Butrimas 1428, strenuus miles (Vitoldiana, p. 46); 1432, namhaftiger ritter (GStA PK, OBA 6095, 6114)

Radvila Astikaitis 1428, strenuus (Vitoldiana, pp. 13-14)

Jonas Goštautas 1429, strenuus (Vitoldiana, p. 157); 1446, gestrenger (GStA PK, OF 16, p. 1154)

Petras Senka Gedgaudaitis 1429, strenuus (CEV, p. 814)

Sudivojus Valmantaitis 1431, namhaftiger und strenger herr (GStA PK, OBA 5636); 1449, gestrenger (GStA PK, OF 17, p. 811) 
Mykolas (court marshal) 1431, strenger ritter (GStA PK, OBA 5858)

Piotr of Kremenec 1434/1443, Божий рылерь (LM, vol. 3, p. 63). Undoubtedly, he was identical with the Volhynian nobleman Piotr Mukosewicz (Halecki, Ostatnie lata, p. 39)

Chodka Jurgaitis 1436, strenuus (Jaworski, 'Z najdawniejszych dokumentów', p. 111)

Jurša 1436, strenuus miles (GStA PK, OBA 7156)

Nemira Riazanovičius 1436, strenuus miles (GStA PK, OBA 7156)

Mykolas Kęsgailaitis 1437, strenuus (KDKW, p. 749)

Butrimas Kęsgailaitis 1437, strenuus (KDKW, p. 749)

Mykolas Daunusaitis of Sviriai 1437, strenuus miles (KDKW, p. 168)

Žostautas of Giedraičiai 1437, strenuus miles (KDKW, p. 168)

Bogusz Owerkicz Timoka of Novgorod Seversk 1438, человекъ рыцерский (AZR, vol. 1, pp. 49-50)

Mantrimas 1439, strenuus (KDKW, p. 172)

Bagdonas Mantrimaitis 1439, strenuus (KDKW, p. 172); 1444, strenuus (ibid., p. 203)

Jonas Nemira 1439, strenuus baro (Bullarium, vol. 5, p. 286, posthumously) Aleksandras Mantautas 1439, miles et baro (Bullarium, vol. 5, p. 286)

Jonas Kęsgailaitis 1442, strenuus vir (KDKW, p. 197)

Dobeslavas Kęsgailaitis 1442, strenuus vir (KDKW, p. 197)

Vaclovas Mangirdaitis 1442, strenuus (KDKW, p. 193)

Jurgis Getautaitis 1443, strenuus (KDKW, p. 202)

Aleksandras Jadogaitis 1443, strenuus (KDKW, p. 202)

Jonas Manvydaitis 1444, strenuus (KDKW, p. 204)

Jurgis Radvilaitis 1444, strenuus (KDKW, p. 203)

Petras Sakaitis 1447, strenger her (GStA PK, OF 16, pp. 1183-1184)

Andrius Davainaitis 1447, gestrenger (GStA PK, OF 16, pp. 1198-1199)

Alekna Sudimantaitis 1449, strenuus (KDKW, p. 220)

Jagintas 1452, strenuus miles (KDKW, p. 240, posthumously)

Rimvydas Jagintaitis 1452, strenuus miles (KDKW, p. 240)

Sačkus Jagintaitis 1452, strenuus dominus (KDKW, p. 240). Most probably the same person as the ruler's marshal strenuus Sačkus mentioned in 1449 (ibid., p. 220)

Jonas Davainaitis 1460, strenuus (KDKW, p. 261, posthumously)

Tautvilas Jonas Mantautaitis 1461, strenuus (KDKW, p. 273); 1461 m. nасаны pыmep (CVIA, f. 525, ap. 8, sv. 395, fo. 18) 
Vazgėla 1461, strenuus (KDKW, p. 273); 1461 m. nасаны рылтер (CVIA, f. 525, ap. 8, sv. 395, fo. 18). It is not clear whether he was identical to Vilnius equerry strenuus dominus Wasgalo mentioned in 1433 (KDKW, p. 147)

Aleksandras Soltanas 1469, miles (Trimoniené, 'Vakarų Europos', p. 113; A. and W. Paravicini, Alexander Soltan, p. 385)

Stanislovas Sudivojaitis 1469, miles (KDKW, p. 301)

Jonas Narbutaitis 1475, gestrenger (CEXV, vol. 3, p. 225)

Albertas Jonaitis Manvydas 1475, ritter (Hiereth, Zeitgenössische Quellen)

Jonas Sapiega 1501, miles (KDKW, p. 568); 1503, miles (ibid., p. 660)

Dobrogostas Narbutaitis 1501, gestrenger her (LUB, vol. 2/2, p. 67)

Jonas Litavoras Chrebtavičius 1510, strenuus miles (LM 8, p. 376)

\section{Abbreviations Used in the Appendix}

AU - Akta unji Polski z Litwa 1385-1791, eds S. Kutrzeba and W. Semkowicz (Cracow, 1932)

Bullarium Poloniae - Bullarium Poloniae, ed. I. SułkowskaKuraś and S. Kuraś, vols 4-5 (Rome-Lublin, 1992-1995)

AZR - Akty Zapadnoi Rossii, vol. 1 (St Petersburg, 1846)

$\mathrm{CEV}$ - Codex epistolaris Vitoldi magni ducis Lithuaniae 1376-1430, ed. A. Prochaska, (Cracow, 1882)

CEXV - Codex epistolaris saeculi decimi quinti, vols 2-3, ed. A. Lewicki (Cracow, 1891-1894)

Joannis Dlugossii Annales seu cronicae - Joannis Dlugossii, Annales seu cronicae incliti Regni Poloniae. Liber decimus et liber undecimus (1406-1412) (Warsaw, 1997); Liber undecimus (1413-1430) (Warsaw, 2000); Liber undecimus et liber duodecimus (1431-1444), ed. D. Turkowska (Warsaw, 2001)

GStA PK - Geheimes Staatsarchiv Preußischer Kulturbesitz, Berlin

Halecki, Ostatnie lata - O. Halecki, Ostatnie lata Świdrygiełty i sprawa wotyńska za Kazimierza Jagiellończyka (Cracow, 1915)

Hiereth, Zeitgenössische Quellen - S. Hiereth, Zeitgenössische Quellen zur Landshuter Fürstenhochzeit (Landshut, 1959)

Jaworski, 'Z najdawniejszych dokumentów' - R. Jaworski, 'Z najdawniejszych dokumentów do dziejów domeny Radziwiłłowskiej', Studia źródłoznawcze, 39 (2001), pp. 101-114 
KDKW - Kodeks dyplomatyczny katedry i diecezji wileńskiej, ed. J. Fijałek and W. Semkowicz (Cracow, 1932-1948)

LM - Lietuvos Metrika. Užrašymu knyga 3, ed. L. Anužytė and A. Baliulis (Vilnius, 1998); Užrašymu knyga 8, ed. A. Baliulis, R. Firkovičius, D. Antanavičius (Vilnius, 1995)

LUB - Liv-, Est- und Curländisches Urkundenbuch, ed. F. G. Bunge et al., Bd. 2, Abt. 2 (Riga-Moscow, 1905)

Paravicini A. und W., Alexander Soltan - Paravicini Anke und Werner, 'Alexander Soltan ex Lithuania ritum grecorum sectans'. Eine ruthenisch-polnische Reise zu den Höfen Europas und zum Heiligen Land 1467-1469, Zwischen Christianisierung und Europäisierung: Beiträge zur Geschichte Osteuropas in Mittelalter und Früher Neuzeit. Festschrift für Peter Nitsche zum 65. Geburtstag, ed. E. Hübner, E. Klug und J. Kusber (Stuttgart, 1998), pp. 367-401

Trimonienè, 'Vakaru Europos' - R. Trimonienè, 'Vakaru Europos valdovų rekomendaciniai raštai Lietuvos didžiojo kunigaikščio Kazimiero dvariškiui. Aleksandro Soltano politinès veiklos štrichai', Lietuvos istorijos studijos, 3 (1996), pp. 101-119

Vitoldiana - Vitoldiana. Codex privilegiorum Vitoldi magni ducis Lithuaniae 1386-1430, ed. J. Ochmański (Warsaw-Poznań, 1986)

Translation: Alfonsas Laučka

Author Details

Dr Rimvydas Petrauskas is an Associate Professor of the Department of Ancient and Medieval History at the Faculty of History, University of Vilnius. His sphere of scholarly interests is political and social history of the Grand Duchy of Lithuania in the 13th-16th centuries.

Address: Department of Ancient and Medieval History, Faculty of History, University of Vilnius, Universiteto 7, LT-01513 Vilnius, Lithuania

Email: rimpet@takas.1t 


\section{RITERIAI LIETUVOS DIDŽIOJOJE KUNIGAIKŠTYSTĖJE}

XIV A. PABAIGOJE - XVI A. PRADŽIOJE

Santrauka

\section{RIMVYDAS PETRAUSKAS}

Vytauto laikais Lietuvoje išryškejja pirmieji naujos gyvenimo tvarkos požymiai, keitę tiek Lietuvos kilmingujų pasaulèžiūrą, tiek elgesio modelius. Europinès gyvenimo formos LDK diduomenę pasiekè pirmaiausia per valdovo dvarą; svarbu buvo ir tai, kad daugejjo diduomenès išvykų i užsienio šalis. Nors Vakarų Europoje tuo metu pradedanti populiarèti bajoriškujų kelionių tradicija Lietuvą pasiekè tik apie XV a. vidurị, ją iš dalies atstojo pasiuntinybès ir didžiojo kunigaikščio lydèjimas į Europos valdovų susitikimus. Reikšmingiausia kilmingujų gyvenimą pakeitusi naujovė buvo riterių kultūros elementų perėmimas. Riterių kultūra vẻlyvaisiais viduramžiais jau išgyveno savo saulèlydị, tačiau ji vis dar buvo pagrindinè Europos kilminguosius vienijanti gyvenimo forma. Kai kurių šios kultūros elementų XIVXVI a. buvo ir Lietuvoje, nors plačiai išsiskleisti čia jie nespejjo. Svarbi Vytauto dvaro gyvenimo dalis buvo îšventinimo į riterius ceremonija. Šalia daugelio Vytauto aplinkos didiku vardų dokumentuose nuolat randamas lotyniškas titulas strenuus (vok. strenger) liudija, kad Vytauto dvare pakèlimo i riterius ceremonialas buvo aktyviai praktikuotas. Vytauto dvaras neabejotinai buvo pagrindinis su riteryste susijusių papročiu ir gyvenimo būdo skleidejas. Tai lèmè tiek paties Vytauto asmeninis domèjimasis šia kultūra, tiek tuo laiku Europos bajorijai būdingos tendencijos. Didžiojo kunigaikščio aplinkoje susitinkantys svetimšaliai ir vietos kilmingieji riterių ritualais tvirtino savo riteriškają tapatybę. Savo dvare burdamas riteriu visuomenę Vytautas siekè sukurti monarcho padèties išskirtinumui neprieštaraujanti valdovo ir kilmingujuc kultūrinị bendrumą ir sukurti savotišką to meto Europos valdovų dvaruose egzistavusio riterių ordino pakaitalą. Socialiniu požiūriu riterystė ir riterių šventimai buvo vienas ženklų, skyrusių diduomenę nuo likusios bajorijos. Nors tokius šventimus turejo teisę gauti visi kilmingieji, tikrovejje tokias galimybes ( tai lëmé padètis dvare, galimybė įsigyti visą reprezentacinę riterišką ekipiruotę) turejo tik siaura žmoniu grupè. Kita vertus, ilgainiui ir diduomenei atrandant naujas išskirtinumo formas, riterystès sąvoka igavo kitą socialinę reikšmę. Dokumentuose didikai pamažu nustoja tituluotis riteriais. Kartu paplinta daugiskaitinis ,riteriu/ riterijos“ ivvardijimas, reiškiantis visus kariauti turinčius ir nešioti ginklą galinčius privilegijuoto luomo asmenis. Tokia luominè riterių kategorija prisidejjo prie vieningo bajorų luomo sampratos isitvirtinimo ir galutinio bajorijos atsiskyrimo nuo kitu socialinių grupių. 